\title{
Dissociable effects of $\mathrm{CB} 1$ receptor blockade on anxiety-like and consummatory behaviors in the novelty-induced hypophagia test in mice
}

\author{
Joyonna C. Gamble-George, Jordan R. Conger, Nolan D. Hartley, Prerna Gupta, Joshua J. \\ Sumislawski, and Sachin Patel \\ Departments of Psychiatry and Molecular Physiology and Biophysics, Vanderbilt University \\ School of Medicine, Nashville, TN 37212
}

\begin{abstract}
Rationale-Central CB1 cannabinoid receptors regulate anxiety-like and appetitive consummatory behaviors. Pharmacological antagonism/inverse-agonism of CB1 receptors increases anxiety and decreases appetitive behaviors; however, neither well-defined dose- nor context-dependence of these effects has been simultaneously assessed in one behavioral assay.
\end{abstract}

Objectives-We sought to determine the context- and dose-dependence of the effects of CB1 receptor blockade on anxiety-like and consummatory behaviors in a model that allowed for simultaneous detection of anxiety-like and consummatory related behaviors.

Methods-We determined the effects of the CB1 receptor antagonist/inverse-agonist, rimonabant, in the novelty-induced hypophagia (NIH) assay in juvenile male ICR mice.

Results-Rimonabant dose-dependently decreased consumption of a palatable reward solution completely independent of contextual novelty. Grooming and scratching behavior was also increased by rimonabant in a context-independent manner. In contrast, rimonabant increased feeding latency, a measure of anxiety-like behaviors, only in a novel, mildly anxiogenic context. The effects of rimonabant were specific since no effects of rimonabant on despair-like behavior were observed in the tail suspension assay. Blockade of CB2 receptors had no effect on noveltyinduced increases in feeding latency or palatable food consumption.

Conclusions-Our findings indicate that CB1 receptor blockade decreases the hedonic value of palatable food irrespective of environmental novelty, whereas the anxiogenic-like effects are highly context dependent. Blockade of CB2 receptors does not regulate either anxiety-like or consummatory behaviors in the NIH assay. These findings suggest rimonabant modulates distinct and dissociable neural processes regulating anxiety and consummatory behavior to sculpt complex and context-dependent behavioral repertories.

\section{Keywords}

Anxiety; depression; rimonabant; SR144528; CB1 receptor; CB2 receptor; cannabinoid; endocannabinoid; stress; anorexia

*Correspondence: Sachin Patel, MD, PhD, Assistant Professor, Departments of Psychiatry and, Molecular Physiology and Biophysics, Robinson Research Building, Rm 724B, Vanderbilt University Medical Center, Nashville, TN 37232, sachin.patel@ vanderbilt.edu, Phone: (615) 936-7768, Fax: (615) 322-1462.

CONFLICT OF INTEREST

The authors declare no financial conflicts of interest. The authors had full control of all data presented herein and will provide original data upon request. 


\section{INTRODUCTION}

Endogenous cannabinoid (eCB) signaling in the central nervous system regulates diverse physiological processes; however, modulation of anxiety and appetitive behaviors are arguably the most robustly modulated by eCB signaling (Chhatwal and Ressler 2007; Di Marzo and Matias 2005; Kirkham and Tucci 2006; Maldonado et al. 2006; Riebe et al. 2012; Serrano and Parsons 2011; Vickers and Kennett 2005; Viveros et al. 2007). With regard to anxiety-like behaviors, low doses of direct $\mathrm{CB} 1$ receptor agonists and indirect CB1 receptor agonists reduce unconditioned anxiety behaviors and can reduce stress-elicited neuroendocrine activation (Kathuria et al. 2003; Kinsey et al. 2010; Patel and Hillard 2006; Patel et al. 2004; Sciolino et al. 2011; Sumislawski et al. 2011). In contrast, blockade of CB1 receptors or genetic deletion of CB1 receptors increases anxiety behaviors (Haller et al. 2002; Navarro et al. 1997; Patel and Hillard 2006), especially under stressful conditions (Haller et al. 2004). These studies suggest strong context-dependent anxiogenic effects of CB1 receptor blockade on anxiety-like behaviors in rodents. These studies support the overall hypothesis that eCBs serve to buffer anxiety and stress responses in an "on demand" basis under challenging environmental conditions (Hill et al. 2010; Lutz 2009; Patel and Hillard 2008). Consistent with this hypothesis, administration of the CB1 receptor antagonist/inverse agonist, rimonabant, can induce anxiety symptoms in a sub-population of human subjects (Christensen et al. 2007).

eCBs are also prominently implicated in the modulation of appetitive behaviors (Cota et al. 2006; Pagotto et al. 2005; Parolaro et al. 2005; Thornton-Jones et al. 2005). Pharmacological blockade of CB1 receptors reduces intake and motivation to obtain palatable food (Arnone et al. 1997; Mathes et al. 2008; Poncelet et al. 2003; Thornton-Jones et al. 2007; ThorntonJones et al. 2005). Similar effects are observed in CB1 receptor knock-out mice (Poncelet et al. 2003). Moreover, both pharmacological blockade and genetic inactivation of the CB1 receptor reduces the motivational effects of several drugs of abuse (Fattore et al. 2010; Gardner 2011; Lopez 2010; Serrano and Parsons 2011; Wiskerke et al. 2008). Conversely, low doses of direct CB1 receptor agonists and endocannabinoids can enhance palatable food consumption and increase hedonic "liking" responses to palatable foods (Mahler et al. 2007). Synthetic cannabinoids and cannabis use are also well known to stimulate appetite in humans (Adams and Martin 1996; Pertwee 1988), and the use of cannabis to treat anorexia associated with malignancy and HIV disease is increasing (Johnson 1990; Nelson et al. 1994; Osei-Hyiaman 2007; Plasse et al. 1991; Struwe et al. 1993; Woolridge et al. 2005). In contrast to the effects on anxiety, the context dependence of the role of eCB signaling in the modulation of appetitive behaviors is not well understood. Furthermore, recent studies have begun to implicate CB2 receptor signaling in reward related processes (Onaivi et al. 2008; $\mathrm{Xi}$ et al. 2011), although further investigations are required to determine the overall contribution of $\mathrm{CB} 2$ receptors in the regulation of appetitive behaviors.

The primary objective of the present study was to utilize a behavioral assay that allowed for the simultaneous detection of possible context-dependent dissociations between the effects of eCB signaling on anxiety-like and appetitive behaviors. Using the novelty-induced hypophagia (NIH) assay (Dulawa and Hen 2005), we found a clear dissociation in contextdependency between the effects of CB1 receptor blockade on anxiety-like and consummatory behavior with only anxiety-like behaviors showing environmental context dependence. 


\section{METHODS}

\section{Animals and drug administration}

Juvenile male ICR mice ( 6 weeks of age) were used for all experiments (Harlan, Indianapolis, IN). All mice were test naïve and used in one experiment only. Mice were housed on a 12:12 light-dark cycle (lights on at 06:00 AM) with food and water available ad libitum. All studies were carried out in accordance with the National Institute of Health Guide for the Care and Use of Laboratory Animals, and approved by the Vanderbilt University Institutional Animal Care and Use Committee. The CB1 receptor antagonist, rimonabant, and CB2 receptor antagonist, SR144528, were a gift from the National Institute of Mental Health Drug Supply Program. Drugs or vehicle were administered by i.p. injection at a volume of $10 \mathrm{ml} / \mathrm{kg}$ in an ethanol:emulphor:saline combination in an 1:1:18 ratio. We chose three different doses of rimonabant $(1,3$, or $10 \mathrm{mg} / \mathrm{kg})$ based on previous studies demonstrating behavioral effects of rimonabant in this dose range (Patel and Hillard 2006; Wiley et al. 2005). We chose similar doses of the CB2 receptor antagonist, SR144528, in order to provide a better comparison between the effects of CB1 and CB2 receptor blockade. Drug pretreatment times were 30 minutes prior to behavioral testing. All behavioral testing was performed during the inactive light phase of the mouse circadian cycle (between 10:00 AM and 04:00 PM).

\section{Open-field locomotor assessment}

To test for open-field locomotor activity in a novel environment, mice were tested for 30 min using automated experimental chambers $(27.9 \times 27.9 \mathrm{~cm}$; MED-OFA-510; MED Associates, St. Albans, Vermont) under constant illumination within a sound-attenuated room as previously described (Sumislawski et al. 2011). All experimental chambers were cleaned in between testing with Vimoba, a chlorine dioxide solution. Activity Monitor v5.10 (MED Associates) was used to analyze open-field activity.

\section{Novelty-induced hypophagia (NIH)}

Individually housed mice (7 days prior to testing) were habituated to a novel, palatable food (Ensure ${ }^{\circledR}$ Homemade Vanilla Shake) in their home cages for $30 \mathrm{~min} /$ day for 3 days before testing. Mice that never fed on the palatable food in their home cages within the habituation period were omitted from testing. The day after habituation ended, mice were presented with the shake in either their home cage (under less aversive, red light illumination, 40 lux) or a novel cage (no bedding, white bottom, under more aversive, high ambient lighting conditions, 295 lux). Red light illumination was used to reduce the aversiveness of the environmental context during home-cage testing. This lighting condition is considered to be in phase with the mouse circadian cycle. Previous studies have suggested that dim, low lighting conditions do not cause changes in behavioral assays that examine locomotor activity and stress-induced effects in ICR male mice (Betancur et al. 1994; Sykes and Henton 1982). The shake was contained in a $50 \mathrm{~mL}$ clear plastic conical tube that was closed by a rubber stopper encasing a metal sipper. Throughout habituation and testing, bedding in the home cage was not changed in order to enable the mice to adapt to being individually housed. For one group of mice, we measured the latency to begin feeding and the amount consumed in two separate experimental cohorts of mice, which were combined for statistical analysis. In the second cohort of mice, we recorded in real-time and analyzed the frequency and duration of drinking, grooming, and scratching over a 30 min test. We defined the mouse behaviors examined in this assay as follows: (1) latency to begin feeding (the amount of time taken to start the first feeding episode); (2) weight consumed (the amount of shake eaten by measuring the difference between the weight of the conical tube containing the shake before and after each test session); (3) drinking (licking the sipper of the conical tube that contained the shake); (4) grooming (licking the fur on the body, paws, and genitals, 
biting the tail, stroking the face with paws, including the whiskers); and (5) scratching (recurring hind paw scratching of the body, neck, ear, and face on the same side of the body) (Tallett et al. 2007a; Tallett et al. 2007b).

\section{Tail-suspension test}

The tail-suspension test is a behavioral assay commonly used to screen antidepressant drugs. The tail suspension test was performed using four chambers under bright light conditions (175 lux) that interfaced with the Tail Suspension software (Version 3.30, MED Associates). All chambers were cleaned in between testing with Vimoba. Mice $(n=10 /$ treatment group) were individually suspended by the tail with adhesive tape from a flat, stainless steel vertical bar in a white plastic cubicle. The total duration of immobility was determined from the accumulated time during which the mouse movement did not exceed a preset threshold of three for $200 \mathrm{~ms}$ and was recorded over a single $5 \mathrm{~min}$ session.

\section{Statistical analysis}

NIH data were analyzed by Two-way ANOVA factoring novelty and drug treatment unless noted otherwise. Effects on latency, consumption, and frequency or duration of drinking, grooming, and scratching were analyzed separately. Post-hoc Sidak's multiple comparisons test was used to determine the effects of drug treatment compared to vehicle treatment in each condition. Open-field and tail-suspension measures were analyzed by One-way ANOVA followed by Dunnett's post-hoc analysis unless noted otherwise. All statistical analyses were conducted with Prism GraphPad 6 (San Diego, CA). Data are presented as mean \pm SEM with $\mathrm{p}<0.05$ considered significant throughout.

\section{RESULTS}

\section{Effects of CB1 receptor blockade on NIH}

During the habituation training, mice quickly approached and consumed the Ensure ${ }^{\circledR}$ confirming the palatability of the solution even in the absence of a food deprivation period (Dulawa and Hen 2005). We determined the effects of 1,3 , or $10 \mathrm{mg} / \mathrm{kg}$ rimonabant on feeding latency and shake consumption during testing in either the home cage or the novel, mildly stressful cage setting. Results revealed a significant effect of drug dose $\left(\mathrm{F}_{(3,133)}=4.96, \mathrm{p}=0.0027\right)$, testing condition $\left(\mathrm{F}_{(1,133)}=67.74, \mathrm{p}<0.0001\right)$, and a significant interaction $\left(\mathrm{F}_{(3,133)}=4.86, \mathrm{p}=0.0031\right.$; Fig 1a). Post-hoc Sidak's multiple comparisons test revealed that rimonabant at $3 \mathrm{mg} / \mathrm{kg}(\mathrm{p}<0.01)$ and $10 \mathrm{mg} / \mathrm{kg}(\mathrm{p}<0.0001)$ significantly increased feeding latency compared to vehicle treatment in the novel testing condition only (Fig. 1a). With respect to the effects of environmental context on feeding latency, post-hoc Sidak's multiple comparisons test also revealed a significant difference between the home and novelty testing condition for all rimonabant treatment groups $(1 \mathrm{mg} / \mathrm{kg}, \mathrm{p}<0.01 ; 3$ and $10 \mathrm{mg} / \mathrm{kg}, \mathrm{p}<0.0001)$. In contrast to the effects on feeding latency, for the shake consumption data (Fig. 1b) Two-way ANOVA revealed a significant effect of drug dose $\left(\mathrm{F}_{(3,133)}=66.84, \mathrm{p}<0.0001\right)$, testing condition $\left(\mathrm{F}_{(1,133)}=12.91, \mathrm{p}=0.0005\right)$, and drug dose $\mathrm{x}$ testing condition interaction $\left(\mathrm{F}_{(3,133)}=3.72, \mathrm{p}=0.013\right)$. Post-hoc Sidak's test revealed that rimonabant significantly decreased shake consumption compared to vehicle treatment in both the home cage $(1 \mathrm{mg} / \mathrm{kg}, \mathrm{p}<0.001 ; 3$ and $10 \mathrm{mg} / \mathrm{kg}, \mathrm{p}<0.0001)$ and novel cage setting $(1,3$, and $10 \mathrm{mg} / \mathrm{kg}, \mathrm{p}<0.0001$ for all $)$. With respect to the effects of environmental context on shake consumption, post-hoc Sidak's multiple comparisons test revealed a significant difference between home and novel condition for the rimonabant treatment group at $1 \mathrm{mg} / \mathrm{kg}$ $(\mathrm{p}=0.0002)$, but no significant difference for the other two doses of rimonabant $(3 \mathrm{mg} / \mathrm{kg}$, $\mathrm{p}=0.9978, \mathrm{NS} ; 10 \mathrm{mg} / \mathrm{kg}, \mathrm{p}=0.9972, \mathrm{NS})$. 
We also determined the effects of 1,3 , or $10 \mathrm{mg} / \mathrm{kg}$ rimonabant on the frequency and duration of shake consumption (drinking), grooming, and scratching during testing in either the home cage or novel cage setting. For the drinking frequency (Fig. 1c, left), results revealed a significant effect of drug dose $\left(\mathrm{F}_{(3,58)}=10.75, \mathrm{p}<0.0001\right)$, but no significant effect of testing condition $\left(\mathrm{F}_{(1,58)}=1.28, \mathrm{p}=0.26\right.$, NS) or interaction $\left(\mathrm{F}_{(3,58)}=0.24, \mathrm{p}=0.87\right.$, NS). Post-hoc Sidak's multiple comparisons test revealed that rimonabant at $1 \mathrm{mg} / \mathrm{kg}(\mathrm{p}<0.05$ home cage; $p<0.01$ novel cage), $3 \mathrm{mg} / \mathrm{kg}$ ( $<<0.05$ for both) and $10 \mathrm{mg} / \mathrm{kg}(\mathrm{p}<0.001$ home cage; $p<0.01$ novel cage) significantly decreased drinking frequency compared to vehicle treatment in both the home and novel testing conditions. For the drinking duration (Fig. 1d, left), results revealed a significant effect of drug dose $\left(\mathrm{F}_{(3,58)}=20.05\right.$, $\left.\mathrm{p}<0.0001\right)$ and testing condition $\left(\mathrm{F}_{(1,58)}=10.59, \mathrm{p}=0.0019\right)$, but no significant interaction $\left(\mathrm{F}_{(3,58)}=2.29, \mathrm{p}=0.088\right.$, NS). Post-hoc Sidak's multiple comparisons test revealed that rimonabant at $1 \mathrm{mg} / \mathrm{kg}$ ( $p<0.05$ home cage; $p<0.001$ novel cage), $3 \mathrm{mg} / \mathrm{kg}$ ( $\mathrm{p}<0.0001$ home cage; $\mathrm{p}<0.001$ novel cage) and $10 \mathrm{mg} / \mathrm{kg}$ ( $\mathrm{p}<0.0001$ home cage; $\mathrm{p}<0.001$ novel cage) significantly decreased drinking duration compared to vehicle treatment in both the home and novel testing conditions, respectively.

For grooming frequency (Fig. 1c, middle), results revealed a significant effect of drug dose $\left(\mathrm{F}_{(3,58)}=15.83, \mathrm{p}<0.0001\right)$, but $n o$ significant effect of testing condition $\left(\mathrm{F}_{(1,58)}=1.86\right.$, $\mathrm{p}=0.18, \mathrm{NS})$ or interaction $\left(\mathrm{F}_{(3,58)}=0.26, \mathrm{p}=0.85\right.$, NS $)$. Post-hoc Sidak's multiple comparisons test revealed that rimonabant at 3 ( $p<0.05$ home cage; $p<0.0001$ novel cage) and $10 \mathrm{mg} / \mathrm{kg}$ ( $\mathrm{p}<0.05$ home cage; $\mathrm{p}<0.001$ novel cage) significantly increased grooming frequency compared to vehicle treatment in both the home and novel testing conditions, respectively. For grooming duration (Fig. 1d, middle), results revealed a significant effect of drug dose $\left(\mathrm{F}_{(3,58)}=9.27, \mathrm{p}<0.0001\right)$, but no significant effect of testing condition $\left(\mathrm{F}_{(1,58)}=0.84, \mathrm{p}=0.36, \mathrm{NS}\right)$ or interaction $\left(\mathrm{F}_{(3,58)}=0.93, \mathrm{p}=0.43\right.$, NS). Post-hoc Sidak's multiple comparisons test revealed that rimonabant at $10 \mathrm{mg} / \mathrm{kg}(\mathrm{p}<0.01)$ in the home testing condition and rimonabant at $3(\mathrm{p}<0.01)$ and $10 \mathrm{mg} / \mathrm{kg}(\mathrm{p}<0.05)$ in the novel testing condition compared to vehicle treatment significantly increased grooming duration.

For scratching frequency (Fig. 1c, right), results revealed a significant effect of drug dose $\left(\mathrm{F}_{(3,58)}=22.29, \mathrm{p}<0.0001\right)$, but $n o$ significant effect of testing condition $\left(\mathrm{F}_{(1,58)}=0.067\right.$, $\mathrm{p}=0.80, \mathrm{NS})$ or interaction $\left(\mathrm{F}_{(3,58)}=1.52, \mathrm{p}=0.22, \mathrm{NS}\right)$. Post-hoc Sidak's multiple comparisons test revealed rimonabant at 3 ( $p<0.01$ home cage; $p<0.001$ novel cage) and 10 $\mathrm{mg} / \mathrm{kg}(\mathrm{p}<0.001$ home cage; $\mathrm{p}<0.0001$ novel cage) significantly increased scratching frequency compared to vehicle treatment in both home and novel testing conditions, respectively. For scratching duration (Fig. 1d, right), results revealed a significant effect of drug dose $\left(\mathrm{F}_{(3,58)}=16.42, \mathrm{p}<0.0001\right)$ and testing condition $\left(\mathrm{F}_{(1,58)}=21.04, \mathrm{p}<0.0001\right)$, but $n o$ significant interaction $\left(\mathrm{F}_{(3,58)}=1.54, \mathrm{p}=0.21\right)$. Post-hoc Sidak's multiple comparisons test revealed rimonabant at $3(\mathrm{p}<0.001)$ and $10 \mathrm{mg} / \mathrm{kg}(\mathrm{p}<0.0001)$ in the home testing condition and rimonabant at $10 \mathrm{mg} / \mathrm{kg}(\mathrm{p}<0.001)$ in the novel testing condition compared to vehicle treatment significantly increased scratching duration.

\section{Effects of CB2 receptor blockade on NIH}

We next tested the effects of the CB2 receptor antagonist/inverse agonist, SR144528, in the $\mathrm{NIH}$ assay in the novel cage setting since this condition yielded effects on both latency and consumption after CB1 receptor blockade ( $\mathrm{n}=8-10 /$ treatment group; data not shown). In contrast to the robust effects observed with rimonabant, One-way ANOVA did not reveal any effect of SR144528 at 1,3 , or $10 \mathrm{mg} / \mathrm{kg}$ on feeding latency $\left(\mathrm{F}_{(3,32)}=0.66, \mathrm{p}=0.58\right.$, NS) or shake consumption $\left(\mathrm{F}_{(3,32)}=0.38, \mathrm{p}=0.77, \mathrm{NS}\right)$ in the novel cage setting. 


\section{Effects of CB1 receptor blockade on locomotor activity}

Administration of the $\mathrm{CB} 1$ receptor antagonist rimonabant caused an increase in horizontal activity counts (Fig. 2a). Two-way repeated measures ANOVA factoring drug dose and time revealed a significant effect of drug dose $\left(\mathrm{F}_{(3,44)}=9.2, \mathrm{p}<0.0001\right)$, time $\left(\mathrm{F}_{(5,220)}=89.0\right.$, $\mathrm{p}<0.0001)$, and dose by time interaction $\left(\mathrm{F}_{(15,220)}=5.68, \mathrm{p}<0.0001\right)$. Post hoc Sidak's test revealed a significant increase in initial locomotor activity during the first $5(\mathrm{p}<0.0001)$ and $10(\mathrm{p}<0.05) \mathrm{min}$ bins of the assay at the $10 \mathrm{mg} / \mathrm{kg}$ dose of rimonabant compared to vehicle treatment. Ambulatory distance was also increased by rimonabant (One-way ANOVA: $\mathrm{F}_{(3,44)}=5.27, \mathrm{p}=0.003 ; 10 \mathrm{mg} / \mathrm{kg}$ vs. vehicle, $\mathrm{p}<0.001$ by Dunnett's post-hoc test; Fig. $\left.2 \mathrm{~b}\right)$. Rimonabant did not affect center time exploration (One-way ANOVA $\mathrm{F}_{(3,44)}=0.59, \mathrm{p}=0.62$, NS; Fig. 2c) or jump time or counts at any dose tested (data not shown).

\section{Effects of CB1 receptor blockade on despair-like behavior}

Neither rimonabant at 3 nor $10 \mathrm{mg} / \mathrm{kg}$ affected duration of immobility over time (Two-way ANOVA effect of drug dose $\mathrm{F}_{(2,27)}=0.27, \mathrm{p}=0.76$, NS) or total \% immobility (One-way $\left.\operatorname{ANOVA~}_{(2,27)}=0.30, \mathrm{p}=0.74, \mathrm{NS}\right)$ in the tail suspension test (data not shown).

\section{DISCUSSION}

Here, we assessed the effects of acute pharmacological CB1 receptor blockade in the NIH test. $\mathrm{CB} 1$ receptor blockade with rimonabant robustly and dose-dependently decreased consumption of a palatable vanilla shake solution, time spent drinking, and the frequency of drinking bouts. This effect was not dependent upon the novelty/aversiveness of the environmental context, since similar effects were observed in animals tested in their familiar home cage, or a mildly anxiogenic novel cage testing condition. In contrast, the effect of rimonabant to increase the latency to begin consuming the palatable solution was robustly increased only in the novel, anxiogenic environmental condition. These data highlight a clear dissociation between the anxiogenic-like effects of rimonabant, operationalized by an increase in feeding latency, and the anti-hedonic effects of rimonabant measured by total shake consumption and drinking time/frequency, with only the former showing environmental context dependence. Other common behaviors induced by rimonabant, including scratching and grooming, did not exhibit context-dependence, with both behaviors being prominent in both home cage and novel cage environments. We also found no evidence that acute $\mathrm{CB} 2$ receptor blockade regulates either anxiety or consummatory behaviors in the NIH assay, and that the effects of rimonabant appear more selective for anxiety-like behaviors relative to despair-like behaviors since no effects of acute CB1 receptor blockade were observed in the tail suspension test.

Over 15 years ago, seminal studies by Le Fur and co-workers demonstrated that administration of rimonabant decreased consumption of sucrose with little effect on nonpalatable food intake (Arnone et al. 1997). Since then, many studies have demonstrated that rimonabant preferentially decreases consumption of palatable food over non-palatable foods (Droste et al. 2010; Mathes et al. 2008; Poncelet et al. 2003; Thornton-Jones et al. 2007; Thornton-Jones et al. 2005); however, this is not a ubiquitous finding (Salamone et al. 2007; Verty et al. 2004). It has been generally acknowledged that blockade of CB1 receptors decreases palatable food intake by decreasing the hedonic value of palatable foods, thereby decreasing the motivation to work for palatable rewards (Droste et al. 2010; Hernandez and Cheer 2012; Salamone et al. 2007). Importantly, rimonabant does not affect Pavlovian approach behaviors in an autoshaping paradigm (Thornton-Jones et al. 2005). These data may be directly relevant to the present findings since the feeding latency in the home cage to some degree is driven by Pavlovian approach behavior. Since latency times were unchanged by rimonabant treatment in the home cage, but shake consumption, drinking time, and 
drinking frequency were all dramatically reduced, our data generally support the hypothesis that $\mathrm{CB} 1$ receptor blockade decreased the hedonic value of palatable solution without affecting the initial expected value of the solution based on previous learning.

The lack of rimonabant effect on feeding latency in the home cage argues against nonspecific behavioral suppression that has been suggested by some to account for the decrease in feeding behavior observed after CB1 receptor blockade. Specifically, Rodgers and coworkers have suggested that CB1 receptor blockade reduces feeding behavior by biasing behavioral repertoires toward grooming-related behaviors (Tallett et al. 2007a; Tallett et al. 2007b). If this were the case in our study, one would expect an increase in feeding latency to accompany the decrease in total consumption in the home cage. However, it could be argued that reduced consumption in the absence of changes in latency could still be due to interference of ongoing drinking behavior by grooming activity despite the initial approach time being unchanged in the home cage. Our subsequent analysis of grooming, scratching, and drinking time suggests this is not the case, however. First, time spent grooming was similar in home and novel cage environments, indicating that grooming behavior did not interfere per se with the ability of mice to approach the sipper since latency times were very low in the home cage, yet grooming time was quite high. Secondly, although time spent grooming was similar between home and novel cage environments, total grooming time was only $\sim 33 \%$ of total testing time at the highest dose of rimonabant, whereas drinking time was only $\sim 5.5 \%$ of total testing time in vehicle treated mice. Therefore, it is unlikely that time spent grooming occupied sufficient testing time to reduce drinking time from $\sim 5.5 \%$ to $\sim 1.5 \%$ in $10 \mathrm{mg} / \mathrm{kg}$ rimonabant treated mice. Even if time spent grooming and scratching are summed, this equals $\sim 44 \%$ of total time, which again is not likely sufficient to preclude drinking for $\sim 5.5 \%$ time as seen in control mice in the novel cage. These data suggest rimonabant-induced anorectic effects are not mediated by behavioral competition with grooming and scratching behaviors. These findings are supported by recent data from Wright and co-workers showing that acute inhibition of food intake by rimonabant is not secondary to compulsive, stereotypic scratching and grooming behaviors in male rats (Wright and Rodgers 2012).

Blockade of CB1 receptors is also known to increase anxiety-like behaviors in rodents (Navarro et al. 1997; Patel and Hillard 2006); however, some studies have demonstrated anti-anxiety effects also (Griebel et al. 2005). Importantly, the anxiogenic effects of both acute pharmacological blockade and genetic CB1 receptor deletion have been shown to be dependent upon the environmental aversiveness of the testing conditions. Haller and coworkers demonstrated that aversive/stressful lighting conditions unmask anxiogenic-like behavioral effects in CB1 receptor knock-out mice (Haller et al. 2004). In addition, we have demonstrated that the ability of rimonabant to increase plasma corticosterone is dependent upon stress exposure (Patel et al. 2004). Moreover, indirect CB1 receptor agonists decrease anxiety preferentially under high stress conditions (Naidu et al. 2007; Patel and Hillard 2006; Sciolino et al. 2011). Taken together these data strongly implicate a contextdependent role for endocannabinoids in the regulation of anxiety-like behaviors. Our findings are wholly consistent with this idea. We find that the increase in feeding latency, generally considered an anxiety-like measure (Dulawa and Hen 2005), was only affected in the novel, stressful environment. The lack of effect on latency in the home cage also rules out nonspecific motor deficits as contributing to these results, as do the generally small effects of rimonabant on motor activity observed in the open-field motor assay. Specifically, an increase in feeding latency could potentially be due to locomotor suppressant effects of the drug treatment as suggested by Jarbe and co-workers (Jarbe et al. 2006); however, we found an increase in locomotor activity after the highest dose of rimonabant ruling out this possibility. This increase in locomotion seen after the $10 \mathrm{mg} / \mathrm{kg}$ rimonabant dose may be due to enhanced dopamine receptor function as previously suggested (Fernandez-Espejo et al. 
2005; Giuffrida et al. 1999). Surprisingly, we did not observe a clear anxiogenic effect in the open-field assay with any dose of rimonabant. Given the above discussion of the contextdependency of rimonabant-induced anxiogenesis, one possible explanation for a lack of effect could be that the environment of the open-field assay was not aversive enough. Taken together with the consumption data, our findings highlight for the first time a clear dissociation of the context-dependence of the effects of rimonabant on anxiety-like and consummatory behaviors, with only anxiety being affected by environmental aversiveness.

Another interesting finding that emerged from our data is the differential sensitivity of various behaviors to CB1 receptor blockade. While the rimonabant-induced anorectic effects appear at the lowest dose, the anxiogenic effect of rimonabant was intermediately sensitive at the $3 \mathrm{mg} / \mathrm{kg}$ dose, and rimonabant-induced hyperactivity was only seen at the highest dose. In addition to the differential context-dependency of these behaviors, the differential dose-dependency further suggests that these behavioral effects are mediated via distinct and partially dissociable neural mechanisms. We speculate this differential dose sensitivity could be related to the level of eCB tone within distinct neural circuits/synapses that regulate these distinct behavioral responses. Specifically, we suggest neural circuits regulating hedonic processes to have the highest level of tonic eCB signaling, and, thus, are most sensitive to CB1 receptor blockade. In contrast, locomotor pathways including cortico-striatal circuits would have the lowest level of regulation of tonic eCB signaling, and therefore only be affected by very high levels of CB1 blockade.

Our data also provide two additional levels of specificity to our findings. First, acute blockade of CB2 receptor had no effect on NIH at any dose tested. This is not altogether surprising given the very low expression of CB2 receptors in the brain under basal conditions (Griffin et al. 1999; Nunez et al. 2004; Onaivi et al. 2006). Secondly, we show that $\mathrm{CB} 1$ receptor blockade at the same doses that robustly affect NIH, do not affect despairlike behavior in the tail suspension test. These data are surprising in light of the positive effects of pharmacological CB1 receptor blockade on despair-like behavior previously published (Griebel et al. 2005; Shearman et al. 2003; Tzavara et al. 2003); however, given the propensity of rimonabant to increase anxiety and depressive symptoms in some humans (Christensen et al. 2007), interpretation of these positive results remains difficult (but see (Haring et al. 2013) for possible explanations).

In conclusion, our data provide evidence for the dissociation of the context dependence of CB1 receptor blockade-induced anxiety-like and anorectic effects. We confirm that anxietylike responses induced by $\mathrm{CB} 1$ receptor blockade are exaggerated under conditions of high environmental aversiveness, and that acute $\mathrm{CB} 2$ receptor blockade has no effect on either anxiety or appetitive consummatory behaviors in the NIH assay. These data suggest CB1 receptor blockade affects dissociable neural processes underlying the generation of anxiety and anorexia to sculpt complex and context-dependent behavioral repertoires.

\section{Acknowledgments}

These studies were supported by the National Institute of Health MH090412 (S.P.). Behavioral studies were conducted at the Vanderbilt Neurobehavioral Core Facility.

\section{References}

Adams IB, Martin BR. Cannabis: pharmacology and toxicology in animals and humans. Addiction (Abingdon, England). 1996; 91:1585-614.

Arnone M, Maruani J, Chaperon F, Thiebot MH, Poncelet M, Soubrie P, Le Fur G. Selective inhibition of sucrose and ethanol intake by SR 141716, an antagonist of central cannabinoid (CB1) receptors. Psychopharmacology (Berl). 1997; 132:104-6. [PubMed: 9272766] 
Betancur C, Dell'Omo G, Alleva E. Magnetic field effects on stress-induced analgesia in mice: modulation by light. Neuroscience letters. 1994; 182:147-50. [PubMed: 7715799]

Chhatwal JP, Ressler KJ. Modulation of fear and anxiety by the endogenous cannabinoid system. CNS spectrums. 2007; 12:211-20. [PubMed: 17329982]

Christensen R, Kristensen PK, Bartels EM, Bliddal H, Astrup A. Efficacy and safety of the weight-loss drug rimonabant: a meta-analysis of randomised trials. Lancet. 2007; 370:1706-13. [PubMed: 18022033]

Cota D, Tschop MH, Horvath TL, Levine AS. Cannabinoids, opioids and eating behavior: the molecular face of hedonism? Brain research reviews. 2006; 51:85-107. [PubMed: 16364446]

Di Marzo V, Matias I. Endocannabinoid control of food intake and energy balance. Nature neuroscience. 2005; 8:585-9.

Droste SM, Saland SK, Schlitter EK, Rodefer JS. AM 251 differentially effects food-maintained responding depending on food palatability. Pharmacology, biochemistry, and behavior. 2010; 95:443-8.

Dulawa SC, Hen R. Recent advances in animal models of chronic antidepressant effects: the noveltyinduced hypophagia test. Neuroscience and biobehavioral reviews. 2005; 29:771-83. [PubMed: 15890403]

Fattore L, Melis M, Fadda P, Pistis M, Fratta W. The endocannabinoid system and nondrug rewarding behaviours. Experimental neurology. 2010; 224:23-36. [PubMed: 20353776]

Fernandez-Espejo E, Caraballo I, de Fonseca FR, El Banoua F, Ferrer B, Flores JA, Galan-Rodriguez B. Cannabinoid CB1 antagonists possess antiparkinsonian efficacy only in rats with very severe nigral lesion in experimental parkinsonism. Neurobiology of disease. 2005; 18:591-601. [PubMed: 15755685]

Gardner EL. Addiction and brain reward and antireward pathways. Advances in psychosomatic medicine. 2011; 30:22-60. [PubMed: 21508625]

Giuffrida A, Parsons LH, Kerr TM, Rodriguez de Fonseca F, Navarro M, Piomelli D. Dopamine activation of endogenous cannabinoid signaling in dorsal striatum. Nature neuroscience. 1999; 2:358-63.

Griebel G, Stemmelin J, Scatton B. Effects of the cannabinoid CB1 receptor antagonist rimonabant in models of emotional reactivity in rodents. Biol Psychiatry. 2005; 57:261-7. [PubMed: 15691527]

Griffin G, Wray EJ, Tao Q, McAllister SD, Rorrer WK, Aung MM, Martin BR, Abood ME. Evaluation of the cannabinoid CB2 receptor-selective antagonist, SR144528: further evidence for cannabinoid CB2 receptor absence in the rat central nervous system. Eur J Pharmacol. 1999; 377:117-25. [PubMed: 10448934]

Haller J, Bakos N, Szirmay M, Ledent C, Freund TF. The effects of genetic and pharmacological blockade of the CB1 cannabinoid receptor on anxiety. The European journal of neuroscience. 2002; 16:1395-8. [PubMed: 12405999]

Haller J, Varga B, Ledent C, Barna I, Freund TF. Context-dependent effects of CB1 cannabinoid gene disruption on anxiety-like and social behaviour in mice. The European journal of neuroscience. 2004; 19:1906-12. [PubMed: 15078564]

Haring M, Grieb M, Monory K, Lutz B, Moreira FA. Cannabinoid CB(1) receptor in the modulation of stress coping behavior in mice: the role of serotonin and different forebrain neuronal subpopulations. Neuropharmacology. 2013; 65:83-9. [PubMed: 23000076]

Hernandez G, Cheer JF. Effect of CB1 Receptor Blockade on Food-Reinforced Responding and Associated Nucleus Accumbens Neuronal Activity in Rats. J Neurosci. 2012; 32:11467-77. [PubMed: 22895729]

Hill MN, Patel S, Campolongo P, Tasker JG, Wotjak CT, Bains JS. Functional interactions between stress and the endocannabinoid system: from synaptic signaling to behavioral output. J Neurosci. 2010; 30:14980-6. [PubMed: 21068301]

Jarbe TU, Ross T, DiPatrizio NV, Pandarinathan L, Makriyannis A. Effects of the CB1R agonist WIN-55,212-2 and the CB1R antagonists SR-141716 and AM-1387: open-field examination in rats. Pharmacology, biochemistry, and behavior. 2006; 85:243-52.

Johnson BA. Psychopharmacological effects of cannabis. British journal of hospital medicine. 1990; 43:114-6. 118-20, 122. [PubMed: 2178712] 
Kathuria S, Gaetani S, Fegley D, Valino F, Duranti A, Tontini A, Mor M, Tarzia G, La Rana G, Calignano A, Giustino A, Tattoli M, Palmery M, Cuomo V, Piomelli D. Modulation of anxiety through blockade of anandamide hydrolysis. Nature medicine. 2003; 9:76-81.

Kinsey SG, O’Neal ST, Long JZ, Cravatt BF, Lichtman AH. Inhibition of endocannabinoid catabolic enzymes elicits anxiolytic-like effects in the marble burying assay. Pharmacology, biochemistry, and behavior. 2010; 98:21-7.

Kirkham TC, Tucci SA. Endocannabinoids in appetite control and the treatment of obesity. CNS \& neurological disorders drug targets. 2006; 5:272-92. [PubMed: 16787229]

Lopez HH. Cannabinoid-hormone interactions in the regulation of motivational processes. Hormones and behavior. 2010; 58:100-10. [PubMed: 19819241]

Lutz B. Endocannabinoid signals in the control of emotion. Curr Opin Pharmacol. 2009; 9:46-52. [PubMed: 19157983]

Mahler SV, Smith KS, Berridge KC. Endocannabinoid hedonic hotspot for sensory pleasure: anandamide in nucleus accumbens shell enhances 'liking' of a sweet reward. Neuropsychopharmacology. 2007; 32:2267-78. [PubMed: 17406653]

Maldonado R, Valverde O, Berrendero F. Involvement of the endocannabinoid system in drug addiction. Trends in neurosciences. 2006; 29:225-32. [PubMed: 16483675]

Mathes CM, Ferrara M, Rowland NE. Cannabinoid-1 receptor antagonists reduce caloric intake by decreasing palatable diet selection in a novel dessert protocol in female rats. American journal of physiology. 2008; 295:R67-75. [PubMed: 18448611]

Naidu PS, Varvel SA, Ahn K, Cravatt BF, Martin BR, Lichtman AH. Evaluation of fatty acid amide hydrolase inhibition in murine models of emotionality. Psychopharmacology (Berl). 2007; 192:61-70. [PubMed: 17279376]

Navarro M, Hernandez E, Munoz RM, del Arco I, Villanua MA, Carrera MR, Rodriguez de Fonseca F. Acute administration of the CB1 cannabinoid receptor antagonist SR 141716A induces anxietylike responses in the rat. Neuroreport. 1997; 8:491-6. [PubMed: 9080435]

Nelson K, Walsh D, Deeter P, Sheehan F. A phase II study of delta-9-tetrahydrocannabinol for appetite stimulation in cancer-associated anorexia. Journal of palliative care. 1994; 10:14-8. [PubMed: 8035251]

Nunez E, Benito C, Pazos MR, Barbachano A, Fajardo O, Gonzalez S, Tolon RM, Romero J. Cannabinoid CB2 receptors are expressed by perivascular microglial cells in the human brain: an immunohistochemical study. Synapse (New York, NY. 2004; 53:208-13.

Onaivi ES, Ishiguro H, Gong JP, Patel S, Meozzi PA, Myers L, Perchuk A, Mora Z, Tagliaferro PA, Gardner E, Brusco A, Akinshola BE, Liu QR, Chirwa SS, Hope B, Lujilde J, Inada T, Iwasaki S, Macharia D, Teasenfitz L, Arinami T, Uhl GR. Functional expression of brain neuronal CB2 cannabinoid receptors are involved in the effects of drugs of abuse and in depression. Ann N Y Acad Sci. 2008; 1139:434-49. [PubMed: 18991891]

Onaivi ES, Ishiguro H, Gong JP, Patel S, Perchuk A, Meozzi PA, Myers L, Mora Z, Tagliaferro P, Gardner E, Brusco A, Akinshola BE, Liu QR, Hope B, Iwasaki S, Arinami T, Teasenfitz L, Uhl GR. Discovery of the presence and functional expression of cannabinoid CB2 receptors in brain. Ann N Y Acad Sci. 2006; 1074:514-36. [PubMed: 17105950]

Osei-Hyiaman D. Endocannabinoid system in cancer cachexia. Current opinion in clinical nutrition and metabolic care. 2007; 10:443-8. [PubMed: 17563462]

Pagotto U, Vicennati V, Pasquali R. The endocannabinoid system and the treatment of obesity. Annals of medicine. 2005; 37:270-5. [PubMed: 16019725]

Parolaro D, Vigano D, Rubino T. Endocannabinoids and drug dependence. Current drug targets. 2005; 4:643-55. [PubMed: 16375682]

Patel S, Hillard CJ. Pharmacological evaluation of cannabinoid receptor ligands in a mouse model of anxiety: further evidence for an anxiolytic role for endogenous cannabinoid signaling. The Journal of pharmacology and experimental therapeutics. 2006; 318:304-11. [PubMed: 16569753]

Patel S, Hillard CJ. Adaptations in endocannabinoid signaling in response to repeated homotypic stress: a novel mechanism for stress habituation. The European journal of neuroscience. 2008; 27:2821-9. [PubMed: 18588527] 
Patel S, Roelke CT, Rademacher DJ, Cullinan WE, Hillard CJ. Endocannabinoid signaling negatively modulates stress-induced activation of the hypothalamic-pituitary-adrenal axis. Endocrinology. 2004; 145:5431-8. [PubMed: 15331569]

Pertwee RG. The central neuropharmacology of psychotropic cannabinoids. Pharmacol Ther. 1988; 36:189-261. [PubMed: 3279430]

Plasse TF, Gorter RW, Krasnow SH, Lane M, Shepard KV, Wadleigh RG. Recent clinical experience with dronabinol. Pharmacology, biochemistry, and behavior. 1991; 40:695-700.

Poncelet M, Maruani J, Calassi R, Soubrie P. Overeating, alcohol and sucrose consumption decrease in CB1 receptor deleted mice. Neuroscience letters. 2003; 343:216-8. [PubMed: 12770700]

Riebe CJ, Pamplona F, Kamprath K, Wotjak CT. Fear relief-toward a new conceptual frame work and what endocannabinoids gotta do with it. Neuroscience. 2012

Salamone JD, McLaughlin PJ, Sink K, Makriyannis A, Parker LA. Cannabinoid CB1 receptor inverse agonists and neutral antagonists: effects on food intake, food-reinforced behavior and food aversions. Physiology \& behavior. 2007; 91:383-8. [PubMed: 17521686]

Sciolino NR, Zhou W, Hohmann AG. Enhancement of endocannabinoid signaling with JZL184, an inhibitor of the 2-arachidonoylglycerol hydrolyzing enzyme monoacylglycerol lipase, produces anxiolytic effects under conditions of high environmental aversiveness in rats. Pharmacol Res. 2011

Serrano A, Parsons LH. Endocannabinoid influence in drug reinforcement, dependence and addictionrelated behaviors. Pharmacology \& therapeutics. 2011; 132:215-41. [PubMed: 21798285]

Shearman LP, Rosko KM, Fleischer R, Wang J, Xu S, Tong XS, Rocha BA. Antidepressant-like and anorectic effects of the cannabinoid CB1 receptor inverse agonist AM251 in mice. Behavioural pharmacology. 2003; 14:573-82. [PubMed: 14665974]

Struwe M, Kaempfer SH, Geiger CJ, Pavia AT, Plasse TF, Shepard KV, Ries K, Evans TG. Effect of dronabinol on nutritional status in HIV infection. The Annals of pharmacotherapy. 1993; 27:82731. [PubMed: 8395916]

Sumislawski JJ, Ramikie TS, Patel S. Reversible gating of endocannabinoid plasticity in the amygdala by chronic stress: a potential role for monoacylglycerol lipase inhibition in the prevention of stress-induced behavioral adaptation. Neuropsychopharmacology. 2011; 36:2750-61. [PubMed: 21849983]

Sykes SM, Henton WW. Control of wheel running by near-ultraviolet light. Physiology \& behavior. 1982; 29:965-70. [PubMed: 7156234]

Tallett AJ, Blundell JE, Rodgers JR. Acute anorectic response to cannabinoid CB1 receptor antagonist/ inverse agonist AM 251 in rats: indirect behavioural mediation. Behavioural pharmacology. 2007a; 18:591-600. [PubMed: 17912043]

Tallett AJ, Blundell JE, Rodgers RJ. Grooming, scratching and feeding: role of response competition in acute anorectic response to rimonabant in male rats. Psychopharmacology (Berl). 2007b; 195:27-39. [PubMed: 17639351]

Thornton-Jones ZD, Kennett GA, Vickers SP, Clifton PG. A comparison of the effects of the CB(1) receptor antagonist SR141716A, pre-feeding and changed palatability on the microstructure of ingestive behaviour. Psychopharmacology (Berl). 2007; 193:1-9. [PubMed: 17372721]

Thornton-Jones ZD, Vickers SP, Clifton PG. The cannabinoid CB1 receptor antagonist SR141716A reduces appetitive and consummatory responses for food. Psychopharmacology (Berl). 2005; 179:452-60. [PubMed: 15821957]

Tzavara ET, Davis RJ, Perry KW, Li X, Salhoff C, Bymaster FP, Witkin JM, Nomikos GG. The CB1 receptor antagonist SR141716A selectively increases monoaminergic neurotransmission in the medial prefrontal cortex: implications for therapeutic actions. Br J Pharmacol. 2003; 138:544-53. [PubMed: 12598408]

Verty AN, McGregor IS, Mallet PE. Consumption of high carbohydrate, high fat, and normal chow is equally suppressed by a cannabinoid receptor antagonist in non-deprived rats. Neuroscience letters. 2004; 354:217-20. [PubMed: 14700735]

Vickers SP, Kennett GA. Cannabinoids and the regulation of ingestive behaviour. Current drug targets. 2005; 6:215-23. [PubMed: 15777191] 
Viveros MP, Marco EM, Llorente R, Lopez-Gallardo M. Endocannabinoid system and synaptic plasticity: implications for emotional responses. Neural plasticity: 52908. 2007

Wiley JL, Burston JJ, Leggett DC, Alekseeva OO, Razdan RK, Mahadevan A, Martin BR. CB1 cannabinoid receptor-mediated modulation of food intake in mice. Br J Pharmacol. 2005; 145:293-300. [PubMed: 15778743]

Wiskerke J, Pattij T, Schoffelmeer AN, De Vries TJ. The role of CB1 receptors in psychostimulant addiction. Addiction biology. 2008; 13:225-38. [PubMed: 18482432]

Woolridge E, Barton S, Samuel J, Osorio J, Dougherty A, Holdcroft A. Cannabis use in HIV for pain and other medical symptoms. Journal of pain and symptom management. 2005; 29:358-67. [PubMed: 15857739]

Wright FL, Rodgers RJ. Low dose naloxone attenuates the pruritic but not anorectic response to rimonabant in male rats. Psychopharmacology (Berl). 2012

Xi ZX, Peng XQ, Li X, Song R, Zhang HY, Liu QR, Yang HJ, Bi GH, Li J, Gardner EL. Brain cannabinoid $\mathrm{CB}(2)$ receptors modulate cocaine's actions in mice. Nature neuroscience. 2011; 14:1160-6. 
a

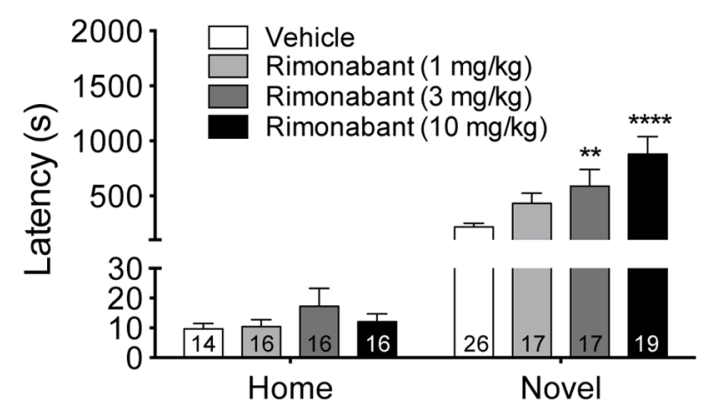

b

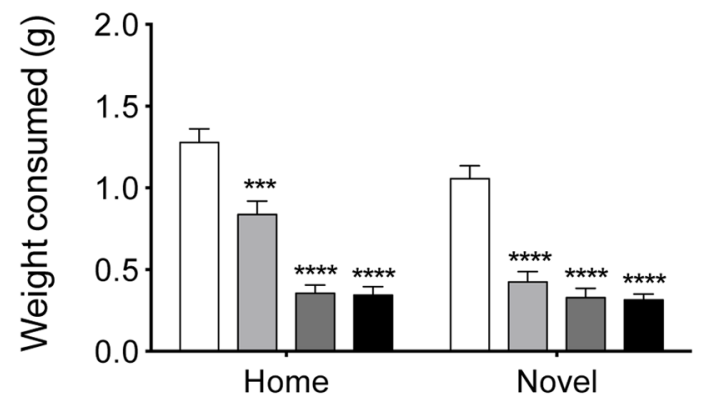

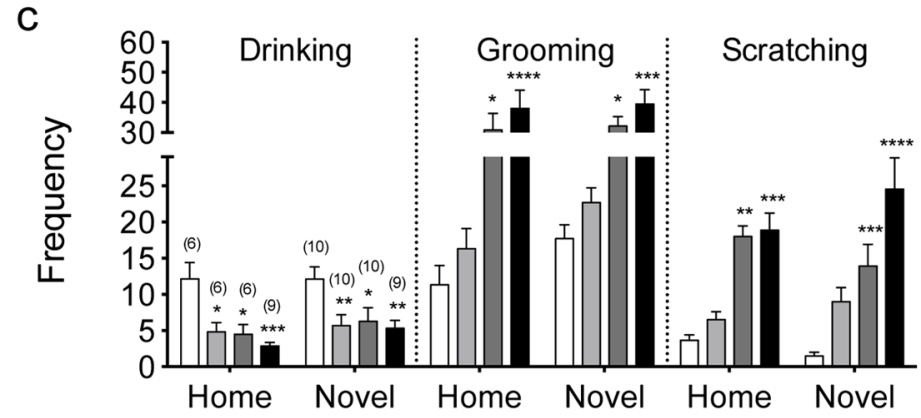

d

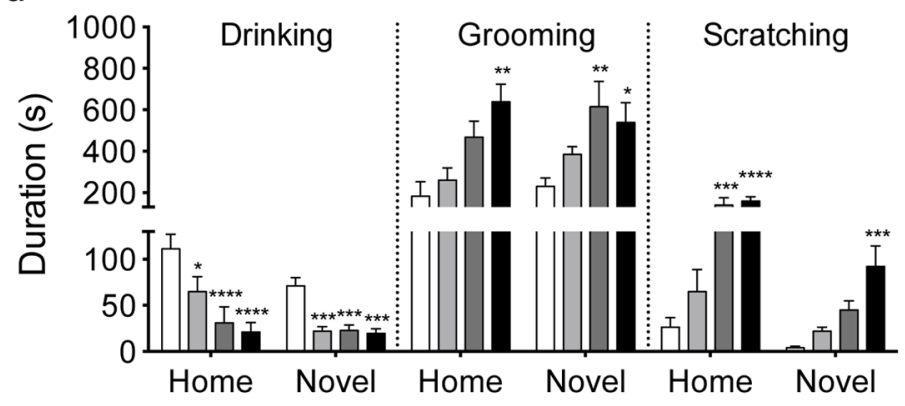

Fig. 1.

Effects of rimonabant on NIH. (a) Effects of the CB1 receptor antagonist, rimonabant (1, 3, or $10 \mathrm{mg} / \mathrm{kg}$ ), on feeding latency during testing in either the home (left) or novel (right) cage setting. (b) Effects of rimonabant (1,3, or $10 \mathrm{mg} / \mathrm{kg}$ ) on shake consumption during testing in either the home (left) or novel (right) cage setting. (c) Effects of rimonabant (1, 3, or $10 \mathrm{mg}$ / $\mathrm{kg}$ ) on frequency of drinking (left panel), grooming (middle panel), and scratching (right panel) during testing in either the home (left) or novel (right) cage setting. (d) Effects of rimonabant $(1,3$, or $10 \mathrm{mg} / \mathrm{kg}$ ) on time duration of drinking (left panel), grooming (middle panel), and scratching (right panel) during testing in either the home (left) or novel (right) cage setting. $* \mathrm{p}<0.05, * * \mathrm{p}<0.01, * * * \mathrm{p}<0.001, * * * * \mathrm{p}<0.0001$ compared to corresponding vehicle treatment by Sidak's post-hoc multiple comparisons analysis. Sample size indicated in bar for (a) and (b) indicated in (a), and indicated above bar in parentheses for (c) and (d) indicated in (c). 
a
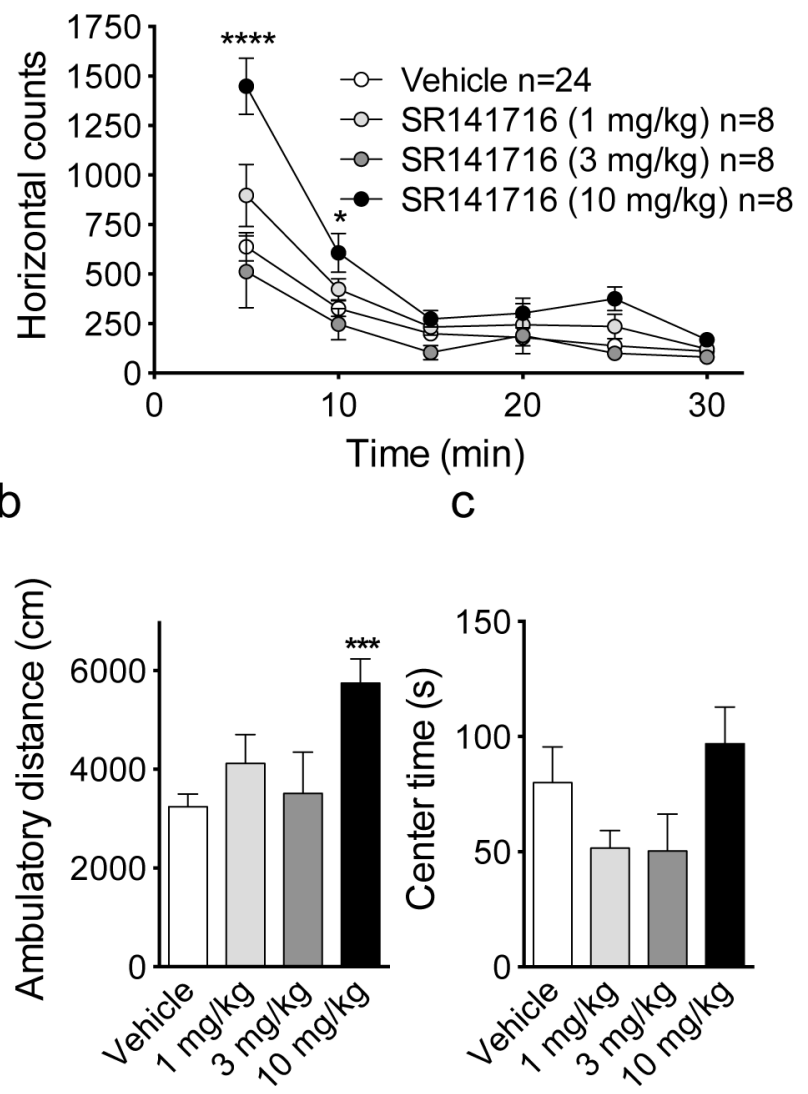

Fig. 2.

Effects of rimonabant on locomotor activity in the open-field test. Effects of rimonabant (1, 3 , or $10 \mathrm{mg} / \mathrm{kg}$ ) on (a) the number of horizontal counts over time, (b) ambulatory distance, and (c) center time exploration in the open-field test. * $\mathrm{p}<0.05, * * * \mathrm{p}<0.001, * * * * \mathrm{p}<0.0001$ relative to corresponding vehicle treatment by Dunnett's post-hoc multiple comparisons analysis. Sample size was 8-24/treatment group. 